\title{
Mites of the genus Neharpyrhynchus Fain (Acariformes, Harpirhynchidae) from Neotropical birds
}

\author{
Andre V. Bochkov ${ }^{1,2, \dagger}$ Ivan Literak ${ }^{3, \uparrow}$ \\ I Zoological Institute, Russian Academy of Sciences, Universitetskaya Embankment 1, 199034 Saint Peter- \\ sburg, Russia 2 Museum of Zoology, University of Michigan, 1109 Geddes Avenue, Ann Arbor, Michigan \\ 48109-1079, U.S.A. 3 Department of Biology and Wildlife Disease, Faculty of Veterinary Hygiene and Eco- \\ logy, University of Veterinary and Pharmaceutical Sciences, Palackeho 1-3, 61242 Brno, Czech Republic \\ † urn:lsid:zoobank.org:author:52DAAF2B-4F09-43A0-AD87-E4DA0C53E920 \\ † urn:lsid:zoobank.org:author:3456E2C0-424E-4AFD-BBE2-F7102AA46ABD \\ Corresponding author: Ivan Literak (literaki@vfu.cz)
}

Academic editor: Vladimir Pešic | Received 28 January 2011 | Accepted 7 March 2011 | Published 11 April 2011

urn:lsid:zoobank.org:pub:91802B35-0B6F-4778-9346-1389BC072A3A

Citation: Bochkov AV, Literak I (2011) Mites of the genus Neharpyrhynchus Fain (Acariformes, Harpirhynchidae) from Neotropical birds. ZooKeys 89: 15-31. doi: 10.3897/zookeys.89.974

\begin{abstract}
Three new species of parasitic mites of the genus Neharpyrhynchus Fain (Acariformes, Harpirhynchidae) are described from Neotropical birds: N. chlorospingus sp. n. from Chlorospingus pileatus (Passeriformes, Emberizidae) from Costa Rica, N. mironovi sp. n. from Dacnys cayana (Passeriformes, Thraupidae) and N. tangara sp. n. from Tangara cayana (Thraupidae) both from Brazil. Neharpyrhynchus trochilinus (Fain) is recorded from 3 new host species of the family Trochilidae (Apodiformes), Panterpe insignis and Eugenes fulgens from Costa Rica, and Amazilia lactea from Brazil. Emended diagnosis of the genus and a key to species are provided; all records of Neharpyrhynchus species are summarized.
\end{abstract}

\section{Keywords}

Acariformes, Harpirhynchidae, Neharpyrhynchus, systematics, birds, parasites

\section{Introduction}

Mites of the genus Neharpyrhynchus Fain (Acariformes, Harpirhynchidae) are permanent and highly specialized parasites of birds, as is the case for all other representatives of the subfamily Harpirhynchinae (Bochkov 2008). The subgenus Neharpyrhynchus

Copyright A.V. Bochkov, I. Literak. This is an open access article distributed under the terms of the Creative Commons Attribution License, which permits unrestricted use, distribution, and reproduction in any medium, provided the original author and source are credited. 
Fain was established by Fain (1972) in the genus Harpirhynchus Mégnin. Later, Fain (1995) proposed full generic status for Neharpyrhynchus and simultaneously revised this genus, which included five species at that time. The life-cycle of these mites was described by Moss et al. (1968) as exemplified by N. novoplumaris Moss et al. The last revision of the genus Neharpyrhynchus was recently provided by Martinu et al. (2008). To date this genus includes 11 species belonging to five species groups established in that revision: baile (3 species), hippolae (3 species), pilirostris (1 species), plumaris (3 species), and squamiferus (1 species). In our opinion, however, there are no characters discriminating the pilirostris and hippolae species groups. Moreover, such differential characters were not provided even by Martinu et al. (2008) and in their key, N. pilirostris is placed in the same couplet with $N$. pari, a species from the group hippolae. We, therefore, include all species of the hippolae group in the pilirostris group.

Most species of the genus are known from European passerines and only two species are known from Neotropical birds, $N$. baile Bochkov et al. from Turdus leucomelas (Passeriformes, Turdidae) (Bochkov et al. 2007) and N. trochilinus (Fain) from hummingbirds (Fain 1972, 1995). In this paper, we describe three new species from Neotropical birds and provide new records for $N$. trochilinus. Additionally, an emended diagnosis of the genus and a key to its species are given. The diagnostic characters of species groups we recognize in the genus Neharpyrhynchus and all records of these mites are given in Tables 1 and 2, respectively.

\section{Material and methods}

Birds were examined by naked eye for the presence of harpirhynchids and released back to the wild. S.V. Mironov and I. Literak examined birds in the field. Mites were cleared in lactophenol and mounted in Hoyer's medium. Specimens were studied using a Leica microscope under Nomarsky interference-contrast-phase (DIC) optics. Drawings were made

Table I. Subdivision of the genus Neharpyrhynchus Fain on species groups. Characters: I Setae $v F$ : smooth (0), serrate (1) 2 Setae 3a: present (0), absent (1) 3 Number of articulated segments of leg I: 4 (0), 2 (1) 4 Number of articulated segments of legs II: 4 (0), 2 (1) 5 Number of articulated segments of legs IV: 2 (0), 1 (1) 6 Ornamentation of anterior region of propodsoma: absent or almost absent (0), present (1).

\begin{tabular}{l|l|l|l|l|l|l|l|l|l}
\hline \multirow{2}{*}{ Groups } & \multicolumn{6}{|c|}{ Characters } & \multicolumn{2}{l}{ Species } \\
\cline { 2 - 6 } & $\mathbf{1}$ & $\mathbf{2}$ & $\mathbf{3}$ & $\mathbf{4}$ & $\mathbf{5}$ & $\mathbf{6}$ & \\
\hline baile & 1 & 0 & 0 & 0 & 1 & 0 & $\begin{array}{l}\text { N. baile Bochkov et al., N. bochkovi Martinu et al., N. tro- } \\
\text { chilinus (Fain) }\end{array}$ \\
\hline plumaris & 0 & 0 & 1 & 1 & 1 & 1 & $\begin{array}{l}\text { N. chlorospingus sp. n., N. novoplumaris (Moss et al.), N. } \\
\text { plumaris (Fritsch), N. spinus Martinu et al. }\end{array}$ \\
\hline pilirostris & 0 & 1 & 1 & 1 & 1 & 1 & $\begin{array}{l}\text { N. hippolae Bochkov, N. mironovi sp. n., N. pari Martinu } \\
\text { et al., N. pilirostris (Berlese \& Trouessart), N. schoenobaenus } \\
\text { Martinu et al., N. tangara sp. n. }\end{array}$ \\
\hline squamiferus & 0 & 0 & 0 & 1 & 0 & 1 & N. squamiferus (Fain) \\
\hline
\end{tabular}


Mites of the genus Neharpyrhynchus Fain (Acariformes, Harpirhynchidae) from...

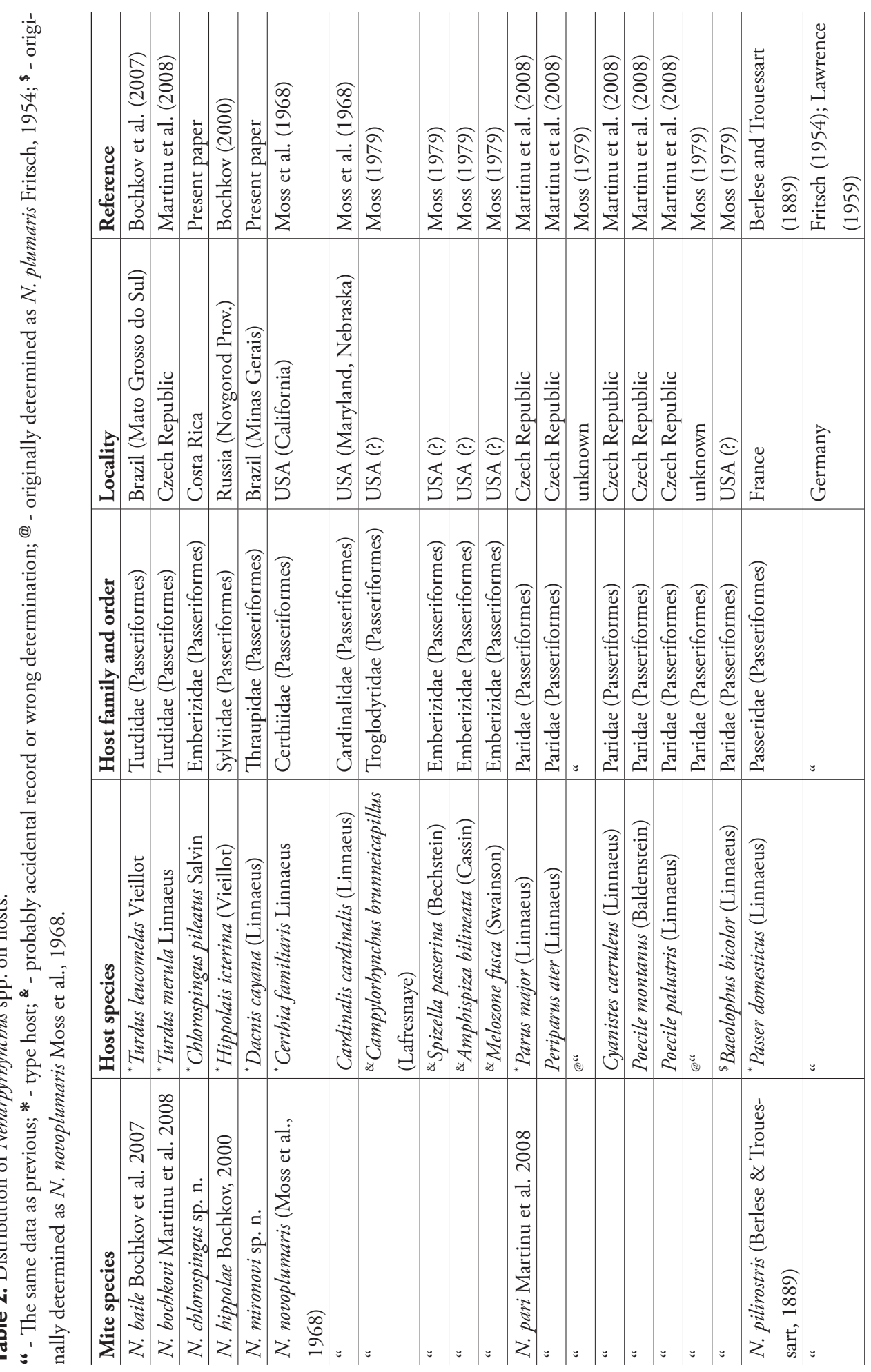




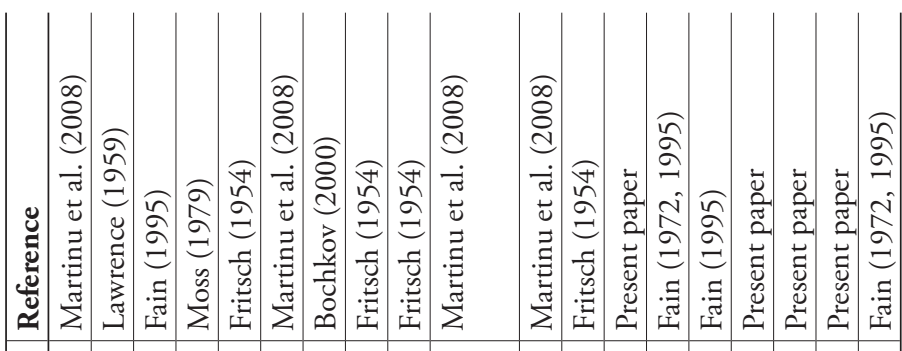

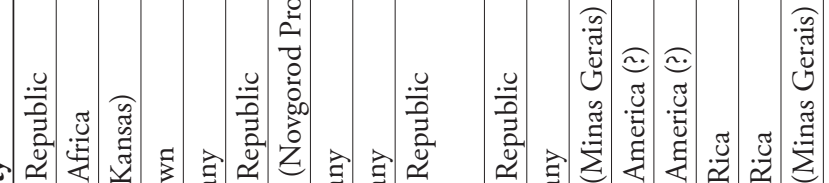
এ

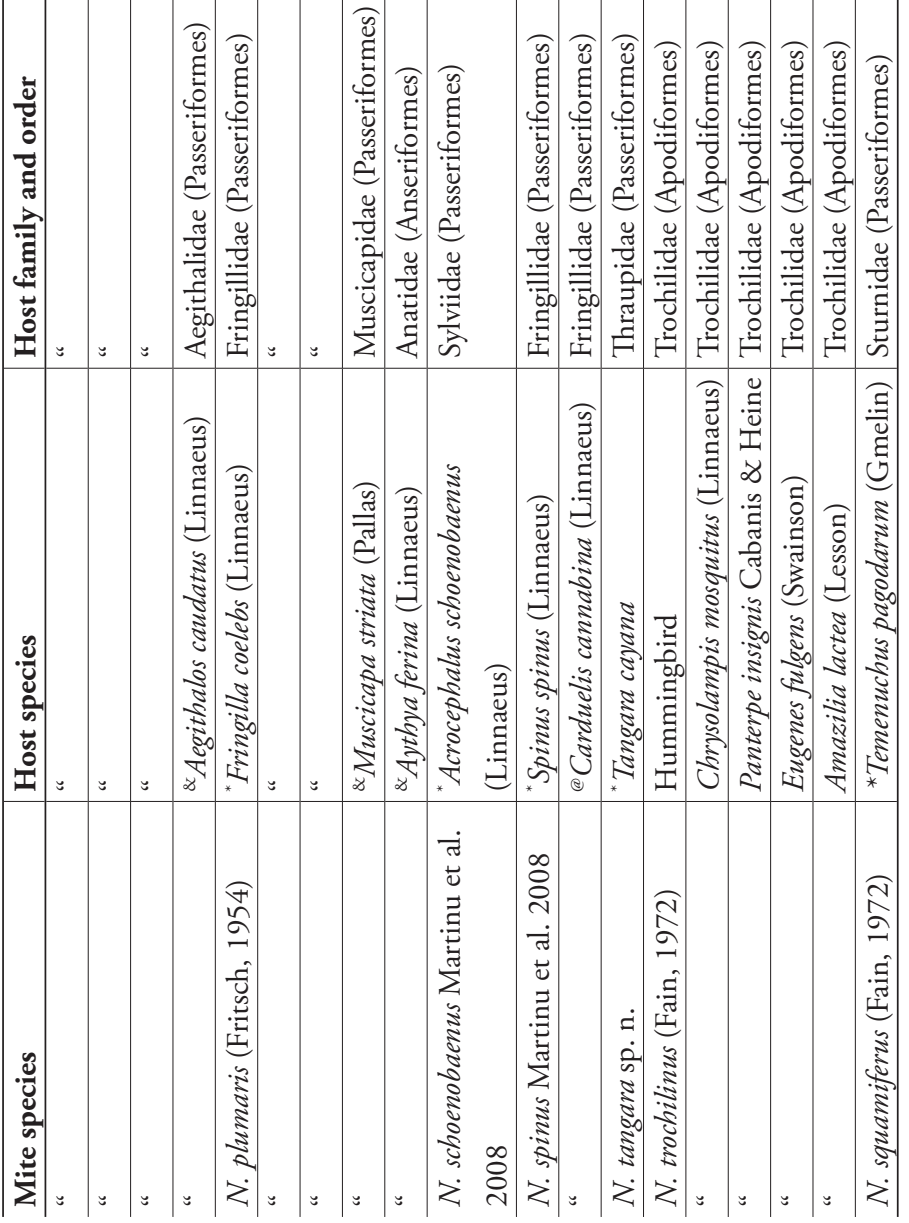


with a camera lucida, and measurements were taken using a calibrated ocular micrometer. Drawings were made by A. V. Bochkov. In the species description, names of the leg and idiosomal setae follow Grandjean $(1939,1944)$ as adapted by Kethley $(1990)$. Names of the palpal setae follow Grandjean (1946) as adapted by Bochkov (2008). All measurements are given in micrometers $(\mu \mathrm{m})$ and were made according to the standard method (Bochkov et al. 2007): body length = maximum length of the body up to the anterior extremity of the palpal tibia; body width = maximum width taken at whatever level it occurs; gnathosomal length = length taken ventrally from the gnathosomal base to the anterior extremity of the palpal tibia; gnathosomal width $=$ maximum width taken at whatever level it occurs; length of dorsal shield = maximum length, measured in the median line of the shield; and width of dorsal shield = maximum width taken at whatever level it occurs.

The scientific names of birds follow the checklist of Clements et al. (2010).
Abbreviations:
CM \#
Ivan Literak field number;
INBio
National Biodiversity Institute (Instituto Nacional de Biodiversidad), Heredia, Costa Rica;
IPCR Institute of Parasitology, Academy of Sciences of the Czech Republic, České Budějovice, Czech Republic
IRSNB Royal Belgian Institute of Natural Sciences (Institut Royal des Sciences Naturelles de Belgique), Brussels, Belgium;
MZUSP Zoological Museum of the University of São Paulo (Museu de Zoolo- gia da Universidade de São Paulo), Brazil;
SVM \# $\quad$ S. Mironov field number;
UMMZ University of Michigan Museum of Zoology, Ann Arbor, USA;
ZISP Zoological Institute of the Russian Academy of Sciences, Saint Peters- burg, Russia;
ZISP AVB \# number in collection of ZISP.

\section{Systematics}

\section{Family Harpirhynchidae Dubinin}

\section{Genus Neharpyrhynchus Fain}

Type species: Harpyrhynchus plumaris Fritsch, 1954: 193, figs 11, 12, by original designation.

Diagnosis. Females. Subcapitulum bearing setae $n, m$, and $e l c p$; palp bearing setae $v F, d F, d G, l " G, d T, l " T, l " T a$. Setae $v F$ smooth or serrate, setae (=palpalae) $d F, d G$, and l" $G$ grouped together, strongly thickened and roughly barbed. Membranous part of palpal tarsi bearing 2 microspurs. Idiosoma saccate. Anterior part of propodonotum sclerotized (see remark below); this sclerotized area smooth or sculptured. Dorsal shield 
distinctly developed, without ornamentation or finely ornamented. Idiosomal setae: $v i, v e$, and $s i$ set close to each other in anterior part of propodosoma, barbed filiform; $s e$ and $c 2$ situated distinctly far from $s i$; $h 1$ - whip-like; $1 a, 1 b$ - fine, smooth filiform; setae $3 a$ present or absent; setae $s c x$ and $a g$ absent. Legs I-II moderately reduced, with distinct basal lobes; their pretarsi with pair of angled claws and ciliated empodium each. Leg I with 2-4 articulated segments. Tarsus I with 8 setae ( $t c^{\prime}, t c^{\prime \prime}, p^{\prime}, p^{\prime \prime}, a^{\prime}, a^{\prime \prime}, u^{\prime}$, $\left.u^{\prime}\right)$ and 1 straight solenidion $\omega 1$ I; tibia I with 5 setae $\left(d, l^{\prime}, l^{\prime \prime}, v^{\prime}, v^{\prime}\right)$, two other proximal segments (if present) devoid of setae. Leg II with $2-4$ articulated segments. Tarsus II with 7 setae (tc', tc', $\left.p^{\prime \prime}, a^{\prime}, a^{\prime \prime}, u^{\prime}, u^{\prime}\right)$ and 1 straight solenidion $\omega$ III; tibia II with 5 setae $\left(d, l, l, v^{\prime}, v^{\prime}\right)$, two other proximal segments (if present) devoid of setae. Posterior legs III and IV bearing 4-6 setae each; legs III with 1 segment, legs IV with 1 or more rarely with 2 segments.

Males. Gnathosoma as in female. Idiosoma rhomboid in outline. Anterior sclerotized area of propodosoma absent. Dorsal shield well developed, occupying most part of dorsal idiosomal surface. Genital opening situated in middle part of dorsal shield. Genital setae 3 pairs. Penis originating behind genital opening. Situations of dorsal idiosomal setae typical for subfamily. Setae $3 a$ present. Legs I and II well developed, without basal lobes, with 5 articulate segments each. Setation of tibia and tarsi as in females, three other proximal segments with setae. Legs III with two segments, both bearing setae; legs IV with one segment.

Species included: $N$. baile Bochkov et al., $N$. bochkovi Martinu et al., $N$. chlorospingus sp. n., $N$. hippolae Bochkov, $N$. mironovi sp. n., $N$. novoplumaris (Moss et al.), $N$. pari Martinu et al., $N$. pilirostris (Berlese \& Trouessart), $N$. plumaris (Fritsch), $N$. schoenobaenus Martinu et al., N. spinus Martinu et al., N. squamiferus (Fain), N. tangara sp. n., and N. trochilinus (Fain).

Hosts: Passeriformes: Aegithalidae, Cardinalidae, Certhiidae, Emberizidae, Fringillidae, Muscicapidae, Paridae, Passeridae, Sturnidae, Sylviidae, Thraupidae, Troglodytidae, Turdidae; Apodiformes: Trochilidae.

Remarks. The sclerotized area on the anterior part of the propodonotum was incorrectly named as the propodosomal (=propodonotal) shield by Martinu et al. (2008). In Harpirhynchidae, actually, the true propodonotal shield is fused with the hysteronotal shield or its remnants to form a common large shield, which can be referred to as the dorsal shield (Bochkov 2008). The sclerotized area in the anterior part of the propodosoma situated anterior to the dorsal shield is formed de novo and probably helps to fix the subcapitulum when the female attaches to a feather (Fig. 1).

\section{Neharpyrhynchus chlorospingus Bochkov \& Literak, sp. n.} urn:Isid:zoobank.org:act:60C5B820-F280-4D12-9C80-BE5B9D9B2BCD Figs 2, 3, 6A

Type material. Female holotype (ZISP H-T-8, AVB 10-1210-001) and 4 female paratypes (ZISP AVB 10-1210-001, 1-4) from Chlorospingus pileatus Salvin (Pas- 


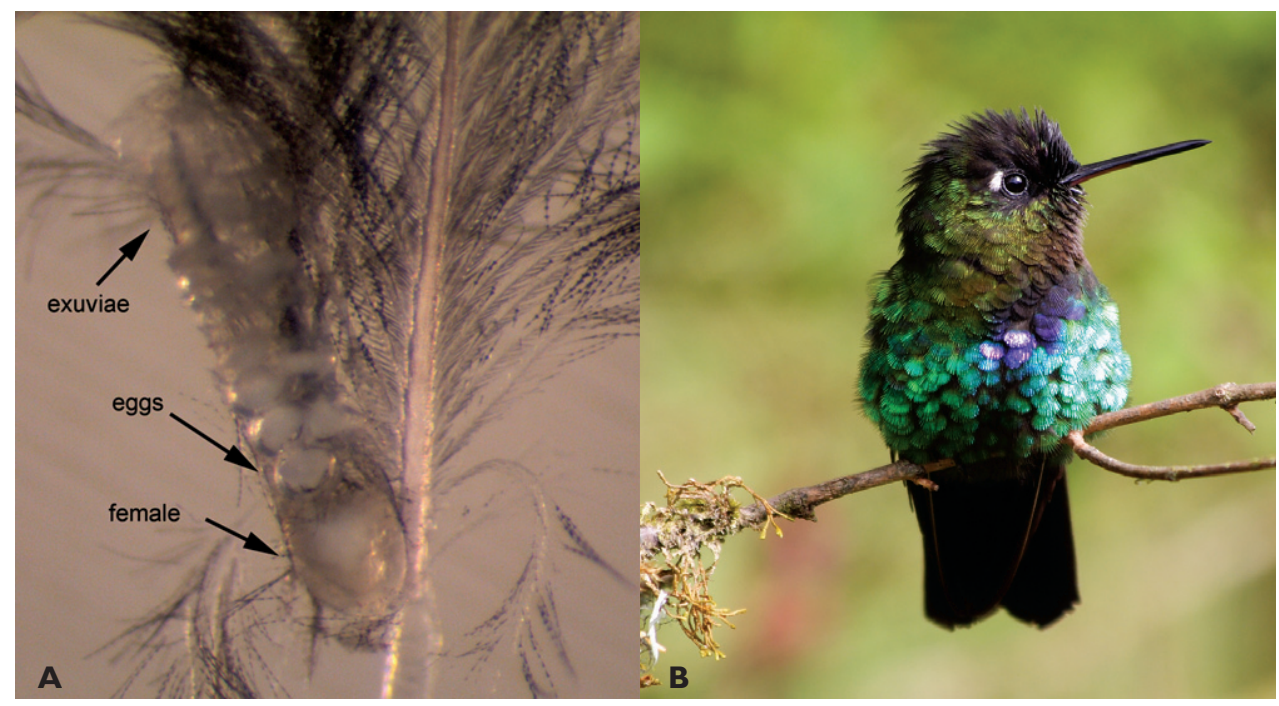

Figure I. A Neharpyrhynchus chlorospingus sp. n., gravid female attached to host feather (photographed by A. V. Bochkov) B Panterpe insignis (Trochilidae) - host of Neharpyrhynchus trochilinus (Fain) (photographed by Z. Literakova).

seriformes, Emberizidae) [feathers around ear apertures], COSTA RICA: Cerro de la Mueste, 9³4'N, 834' W, 13 August 2010, coll. I. Literak et al. (CM 112).

Type deposition. Holotype and 3 paratypes deposited in the ZISP, one paratype in the INBio.

Description. Female (holotype). Idiosoma, including gnathosoma, 525 long ( 500 550 in 3 paratypes), 360 wide (350-360) (Fig. 2). Gnathosoma 130 long (130-145), 130 wide (130-140). Palps 50-60 long, moderately inflated dorsally. All palpalae distinctly pectinate (Fig. 3A). Lengths of palpalae: $d F 35$ (35-35), $d G 20$ (20-25), and $l " G 50$ (40-50); $d G$ slightly thicker and about 2 times shorter than $d F$ and l"G. Setae $v F$ 100-110 long, smooth. Subcapitulum ventrally with setae $n$ and $m$, about 40 and 50 long, respectively. Peritremal branch about 85 long. Idiosoma 425 long (420-440). Anterior region of propodonotum covered by short irregularly situated folds, without scales or tubercles (Fig. 6A). Dorsal shield entire, 165 long in midline (160-170), 300 at maximum width (300-330) (Fig. 2A). Anterior and posterior margins of dorsal shield widely concave. Ventral surface of idiosoma with indistinct transverse striations, without scales or verrucosities (Fig. 2B). Setal lengths: $v i$, ve, and $s i$ - all distinctly barbed, subequal in length, 150-160; se, $c 2$, and $1 a$ - all smooth, 10-12; h1 whip-like, 250 (230-260); $1 b$ smooth, about 40; $3 a$ present, about 20 . Base of legs I with distinctly developed and slightly attenuated fleshy lobe; base of legs II with moderately developed rounded lobe. Leg I with 2 articulated segments (Fig. 3B). Leg II with 2 articulated segments (Fig. 3C). Legs III, IV with one segment, each bearing 4 (more rarely 5) long setae. One ventral seta of leg III and 2 ventral seta of leg IV 100-120 long, about half the length of other setae situated dorsally or dorsoterminally, 200-250 long. 


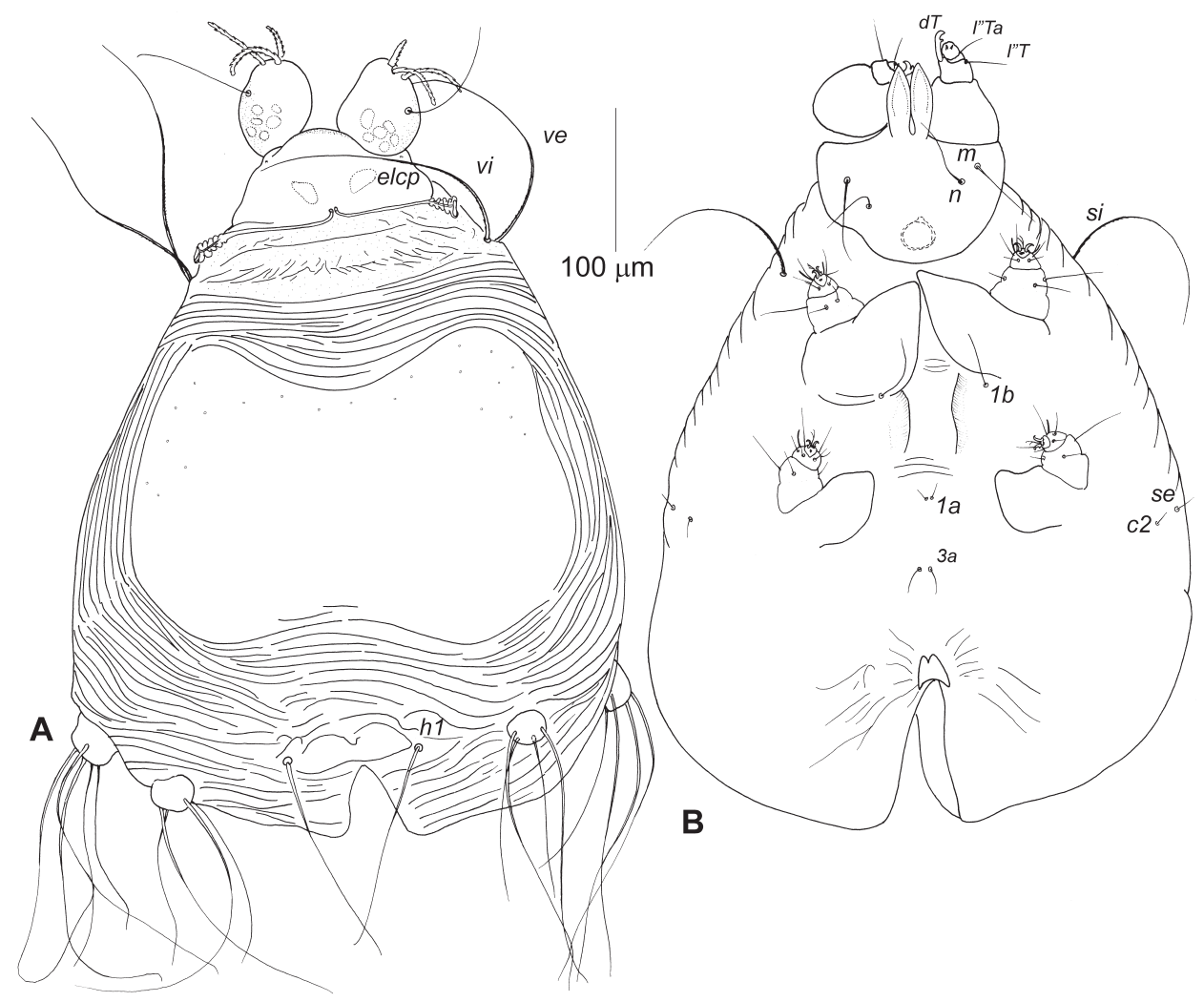

Figure 2. Neharpyrhynchus chlorospingus sp. n., female holotype, A dorsal view B ventral view.

Male. Unknown.

Etymology. The species name is derived from the generic name of the host and is a noun in apposition.

Differential diagnosis. This species belongs to the "plumaris" species group including three species, $N$. plumaris (Fritsch), $N$. novoplumaris (Moss et al.), and N. spinus Martinu et al. (Martinu et al. 2008). In females of this group, legs I and II consist of the two articulated segments, palpal setae $v F$ are smooth, the anterior region of the propodonotum is covered by short irregular striations, and setae $3 a$ are present. Within this group, it is close to $N$. novoplumaris described from Certhia familiaris Linnaeus (Passeriformes, Certhiidae) [type host] and Cardinalis cardinalis (Linnaeus) (Passeriformes, Cardinalidae) from USA (Moss et al. 1968). In females of both of these species setae $d G$ are about half the lenth of $l$ " $G$. In the other two species of the genus, setae $d G$ and $l$ " $G$ are subequal. Females of $N$. chlorospingus differ from $N$. novoplumaris by the following characters. In $N$. chlorospingus, palpal setae $d F$ are slightly shorter than l" $G$, setae se and $c 2$ are about four times shorter than $1 b$, the posterior margin of the dorsal shield is widely concave. In $N$. novoplumaris, palpal setae $d F$ are slightly longer than $l$ " $G$, setae se and $c 2$ are subequal or only slightly shorter than $1 b$, the posterior margin of the dorsal shield is widely convex. 


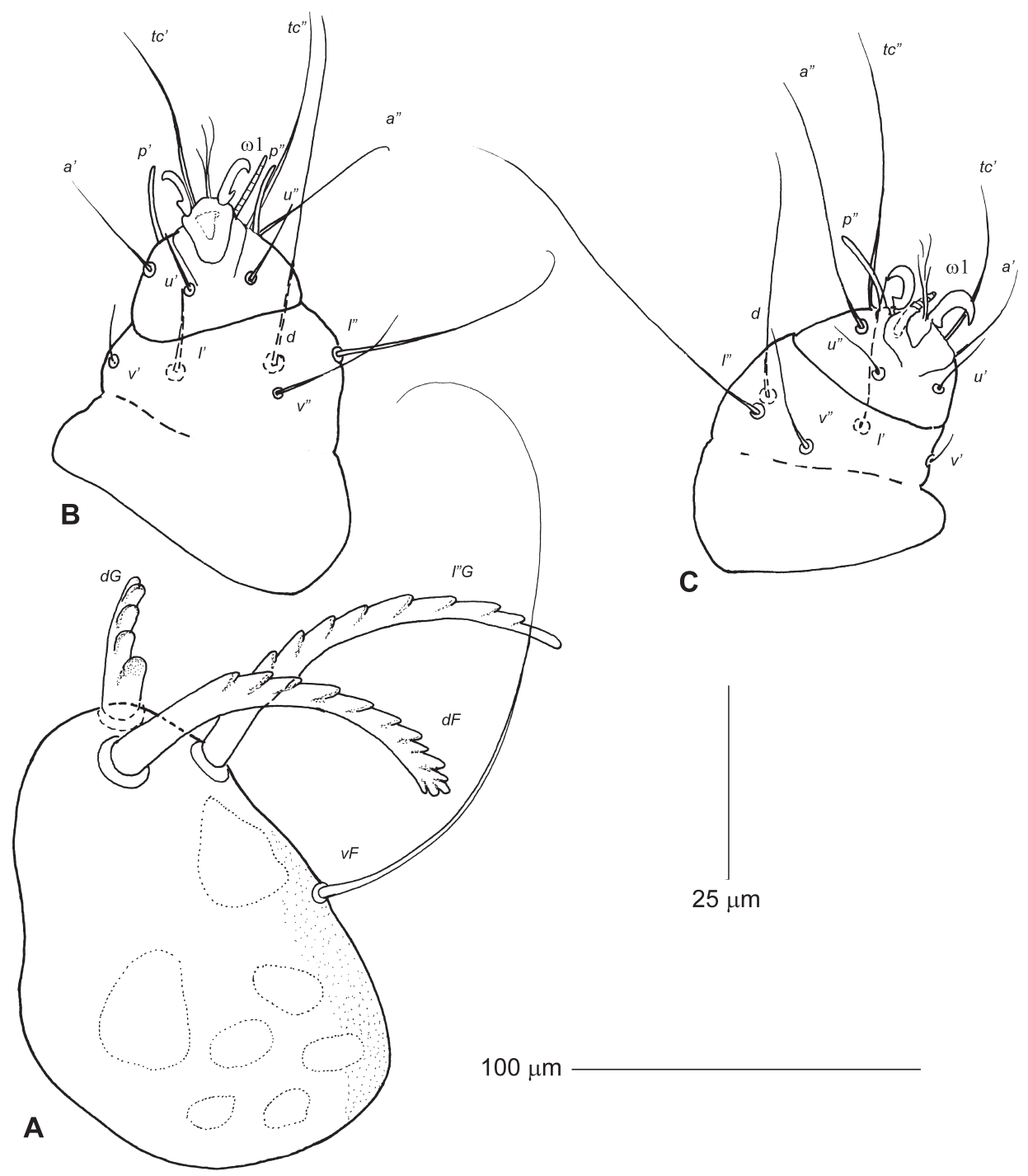

Figure 3. Neharpyrhynchus chlorospingus sp. n., details of female holotype, A palp in dorsal view B leg I in dorsal view $\mathbf{C}$ leg II in dorsal view.

\section{Neharpyrhynchus mironovi Bochkov \& Literak, sp. n.} urn:Isid:zoobank.org:act:07B0EB50-C713-417B-AAA4-0B240A93AA7D Figs 4, 5A-C, 6B

Type material. Female holotype (MZUSP), 20 female paratypes (ZISP AVB 10-1210002, \#1-20) on slides and numerous paratypes preserved in alcohol from Dacnis cayana (Linnaeus) (Passeriformes, Thraupidae) [feathers around ear apertures, back of the 


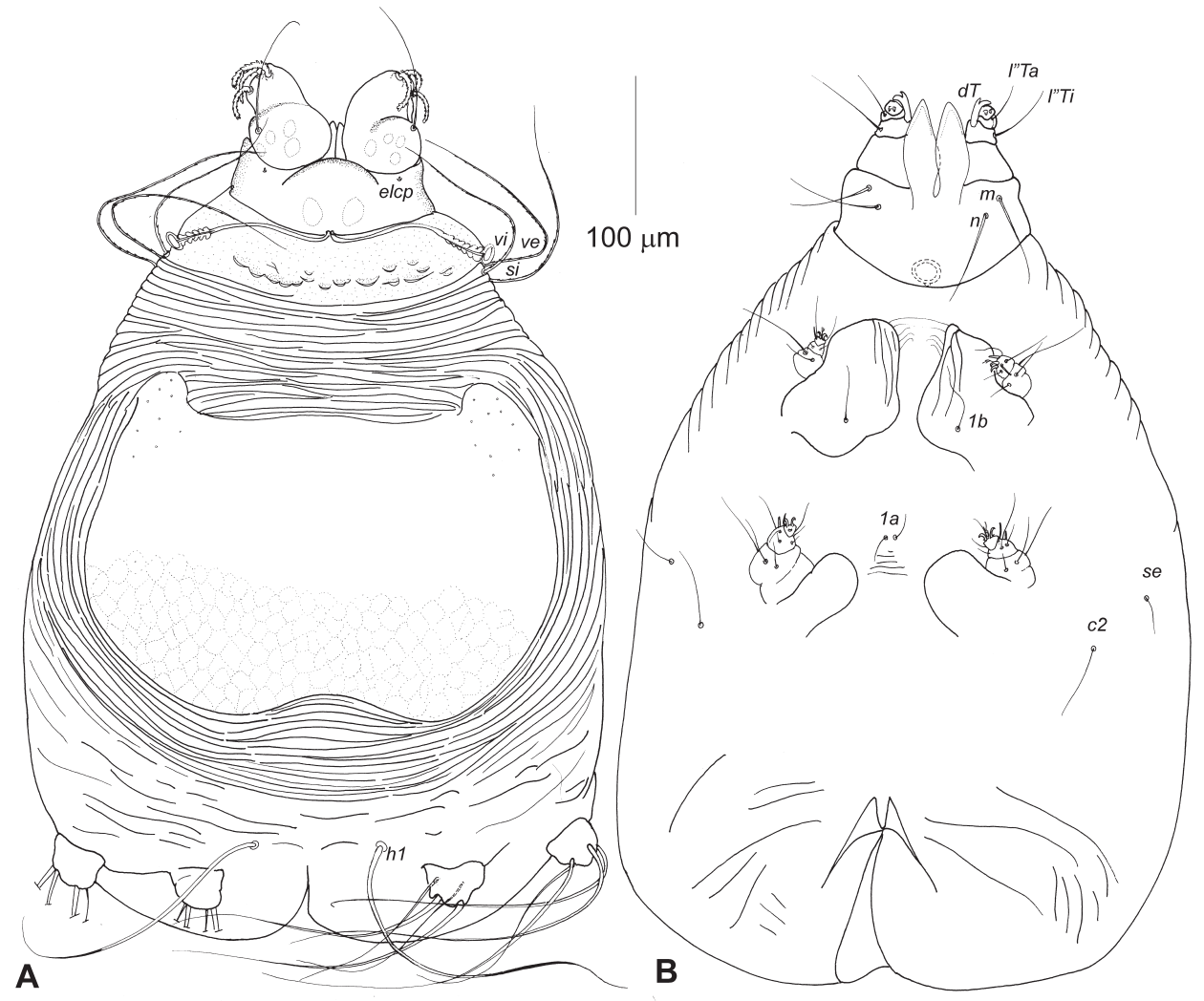

Figure 4. Neharpyrhynchus mironovi sp. n., female holotype, A dorsal view B ventral view.

head and neck], BRAZIL: Minas Gerais, Belo Horizonte, Nova Lima, Área de Proteção Permanente (Permanent area for protection) do Condomínio Miguelão, 2007'S, $43^{\circ} 58^{\prime} \mathrm{W}, 8$ September 2010, coll. S.V. Mironov et al. (SVM-10-0908-1).

Type deposition. Holotype and 10 paratypes deposited in the MZUSP, 6 paratypes in the ZISP, 2 paratypes in the UMMZ, and 2 paratypes in the IPCR. Alcohol preserved paratypes deposited in the MZUSP and ZISP.

Description. Female (holotype). Idiosoma, including gnathosoma, 675 long (660-680 in 10 paratypes), 425 wide (420-435) (Fig. 4). Gnathosoma 135 long (130-140), 150 wide (140-155). Palps 65-75 long, distinctly inflated dorsally. All palpalae distinctly pectinate (Fig. 5A). Lengths of palpalae: $d F 40$ (38-40), $d G 30$ (2833 ), and $l " G 30$ (30-35); $d F$ only slightly longer than $d G$ and $l " G$. Setae $v F$ about 100 long, smooth. Subcapitulum ventrally with setae $n$ and $m$, about 80 long. Peritremal branch about 120 long. Idiosoma 525 long (510-530). Anterior region of propodonotum covered by short rounded scales situated irregularly in its posterior half (Fig. 6B). Dorsal shield entire, 200 long in midline (190-200), 350 at maximum width (350370) (Fig. 4A). Anterior margin of dorsal shield almost straight, with pair of lateral 

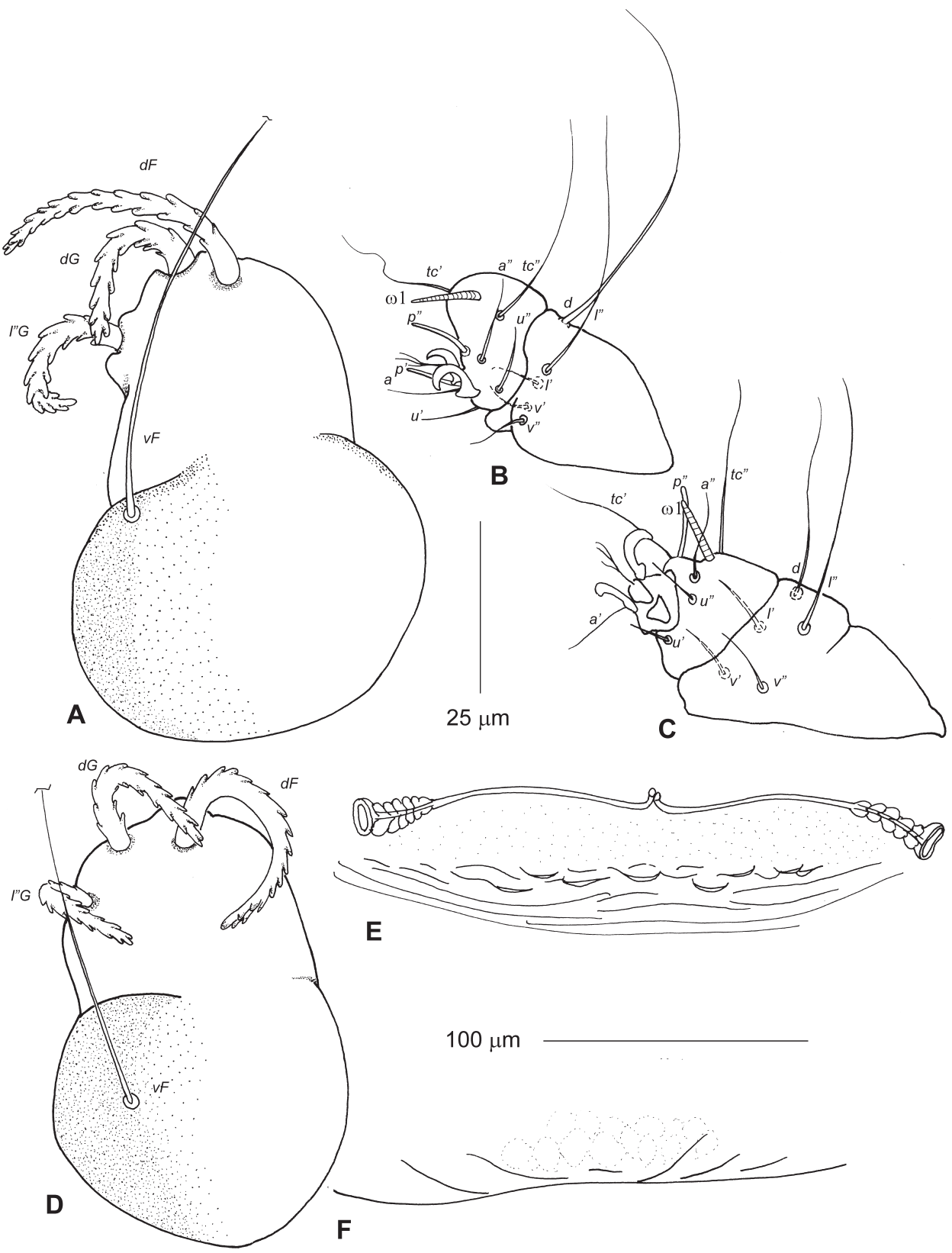

Figure 5. Neharpyrhynchus spp, details of females. $N$. mironovi sp. n., holotype (A-C), A palp in dorsal view $\mathbf{B}$ leg I in dorsal view $\mathbf{C}$ leg II in dorsal view; $N$. tangara sp. n. (D-F), D palp in dorsal view $\mathbf{E}$ anterior part of propodonotum $\mathbf{F}$ posterior margin of dorsal shield. Scale bars: $\mathbf{A}-\mathbf{D}=25 \mu \mathrm{m} ; \mathbf{E}$ and $\mathbf{F}=100 \mu \mathrm{m}$. 

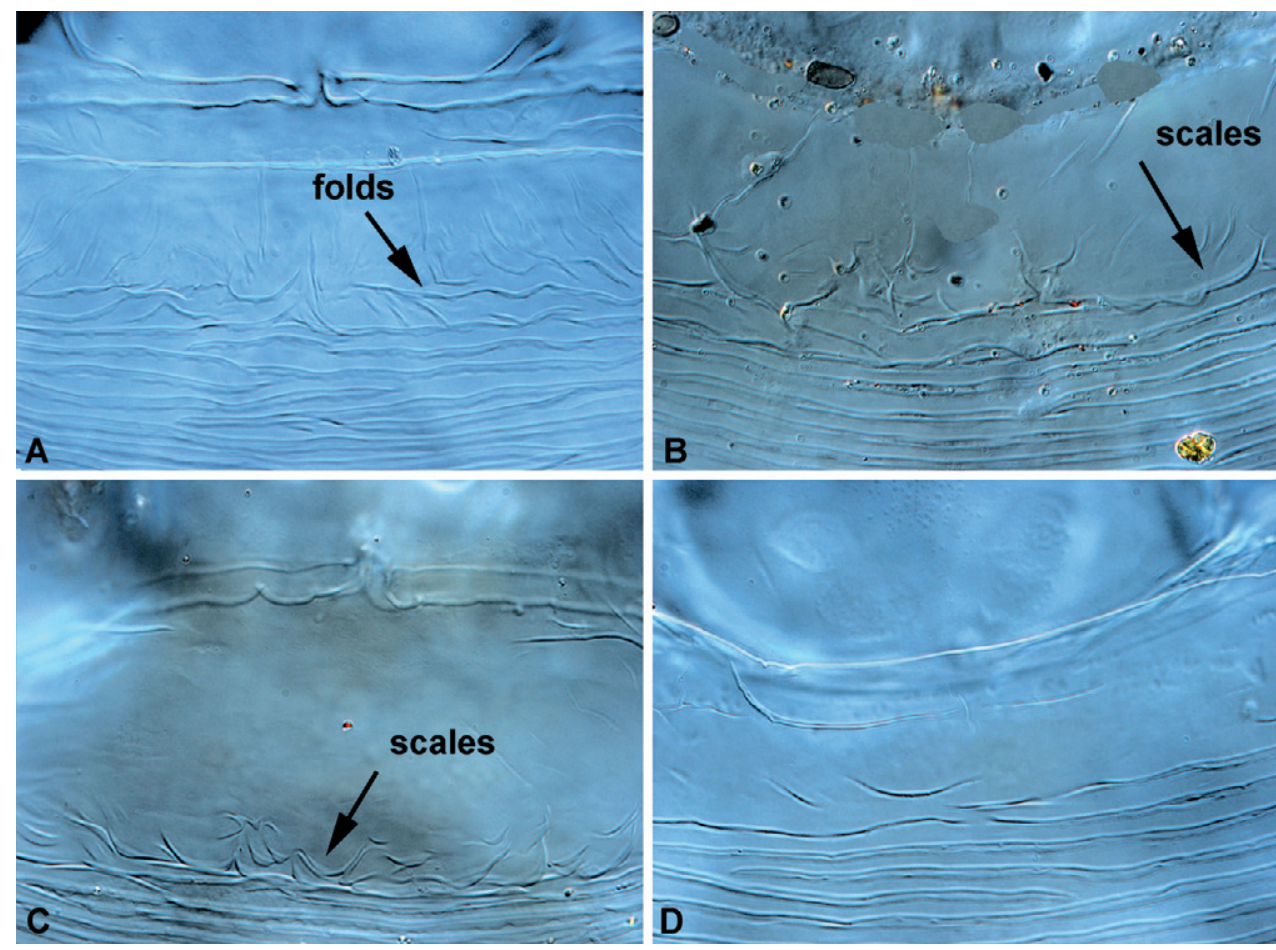

Figure 6. Neharpyrhynchus spp, anterior part of propodonotum, A $N$. chlorospingus sp. n. B N. mironovi sp. n. C $N$. tangara sp. n. D N. trochilinus (Fain).

anteriorly directed projections; posterior margin with distinct median concavity. This shield covered by fine rhomboid-like pattern, almost indistinct in anterior half and more clearly discernible in posterior half. Ventral surface of idiosoma with indistinct transverse striations, without scales or verrucosities (Fig. 4B). Setal lengths: $v i$, ve, and $s i$ - all distinctly barbed, subequal in length, 160-175; se and 1a 12-25, c2 50-60 - all smooth; h1 whip-like, 250 (250-280); $1 b$ smooth, 30-40, 3a absent. Base of legs I with distinctly developed fleshy lobe partially covering leg segments; base of legs II with moderately developed rounded lobe. Leg I with 2 articulated segments (Fig. 5B). Leg II with 2 articulated segments (Fig. 5C). Legs III, IV with one segment, each bearing 4 long setae. One ventral seta of leg III and 2 ventral seta of leg IV about 150 long, about half the length of other setae situated dorsally or dorsoterminally, 250-300 long.

Male. Unknown.

Etymology. The species is named in honour of the prominent Russian acarologist Dr. Sergey V. Mironov (ZISP).

Differential diagnosis. It is close to species of the group "pilirostris". In all these species, setae $v F$ are smooth, only two articulated segments on legs I and II are present, and setae $3 a$ are absent. Among species of this group, $N$. mironovi is close to $N$. pari by the presence of four setae on leg III and by irregular ornamentation of the anterior part of the propodosoma. The new species differs from $N$. pari by the following characters. 
In females of $N$. mironovi, the palps are distinctly inflated dorsally, the ornamentation of the anterior part of the propodonotum is scale-like and present only in the posterior half of this region, setae $c 2$ are 50-60 long. In $N$. pari, the palps are moderately inflated dorsally, the anterior part of the propodonotum is fully ornamented by verrucosities and setae $c 2$ are 5-6 long.

\section{Neharpyrhynchus tangara Bochkov \& Literak, sp. n.} urn:Isid:zoobank.org:act:5C1328B7-9A79-445A-AFB6-BC5402DFC36C Fig. 5D-F, 6C

Type material. Female holotype (MZUSP), 20 female paratypes (ZISP AVB 10-1210003, 1-20) on slides and numerous paratypes preserved in alcohol from Tangara cayana (Linnaeus) (Passeriformes, Thraupidae) [feathers around ear apertures, back of the head and neck], BRAZIL: Minas Gerais, Belo Horizonte, Nova Lima, Água Limpa, $20^{\circ} 13^{\prime} \mathrm{S}, 43^{\circ} 56^{\prime} \mathrm{W}, 31$ August 2010, coll. S.V. Mironov et al. (SVM-10-0831-12).

Type deposition. Holotype and 10 paratypes deposited in the MZUSP, six paratypes in the ZISP, 2 paratypes in the UMMZ, and 2 paratypes in the IPCR. Alcohol preserved paratypes deposited in the MZUSP and ZISP.

Description. Female (holotype). Idiosoma, including gnathosoma, 600 long (600-620 in 10 paratypes), 380 wide (380-400). Gnathosoma 125 long (125-130), 150 wide (145-150). Palps 60 long, distinctly inflated dorsally. All palpalae distinctly pectinate (Fig. 5D). Lengths of palpalae: $d F 35$ (35-40), $d G 30$ (29-33), and l"G 29 (30-32); $d F$ only slightly longer than $d G$ and $l " G$. Setae $v F$ about 90 long, smooth. Subcapitulum ventrally with setae $n$ and $m$, about 70 long. Peritremal branch about 110 long. Idiosoma saccate, 500 long (500-520). Anterior region of propodonotum covered by short rounded scales situated irregularly in its posterior half (4E, $5 \mathrm{C})$. Dorsal shield entire, 190 long in midline (180-200), 330 at maximum width (330-350). Anterior margin of dorsal shield almost straight with pair of lateral anteriad directed projections; its posterior margin almost straight $(4 \mathrm{~F})$. This shield covered by fine rhomboid-like pattern, almost indistinct in anterior half and slightly better discernible in posterior half. Ventral surface of idiosoma with indistinct transverse striations, without scales or verrucosities. Setal lengths: $v i$, ve, and $s i$ - all distinctly barbed, subequal in length, 150-170; se, $c 2$, and $1 a$ 8-12 - all smooth; h1 whip-like, 230 (210-240); $1 b$ smooth, 30-35, $3 a$ absent. Legs as in previous species.

Male. Unknown.

Etymology. The species name derives from the generic name of the host and is a noun in apposition.

Differential diagnosis. This new species is closest to $N$. mironovi and differs by the following characters. In females of $N$. tanagra, setae $c 2$ are 8-12 long, the posterior margin of the dorsal shield is almost straight. In N. mironovi, setae $c 2$ are 50-60 long, the posterior margin of the dorsal shield is widely concave. Both species are collected from the hosts belonging to the family Thraupidae. 


\section{Neharpyrhynchus trochilinus (Fain, 1972)}

Fig. 6D

Harpyrhynchus (Neharpyrhynchus) trochilinus Fain, 1972: 55.

Neharpyrhynchus trochilinus Fain 1995: 80, figs 17, 18; Bochkov et al. 2007: 38; Martinu et al. 2008: 207, fig. 1 [types in IRSNB].

Material examined. 26 females (ZISP AVB 10-1210-004, 1-26) from Panterpe insignis Cabanis \& Heine (Apodiformes, Trochilidae) [feathers of neck], COSTA RICA: Cerro de la Mueste, 934'N, 83ํ5' W, 14 August 2010, coll. I. Literak et al. (CM 199); 10 females from same host (ZISP AVB 10-1210-005,1-10) and locality, 11 August 2010, coll. I. Literak et al. (CM 13); 10 females (ZISP AVB 10-1210-006, 1-10) from same host and locality, 13 August 2010, coll. I. Literak et al. (CM 151).

20 females (ZISP AVB 10-1210-007, 1-20) from Eugenes fulgens (Swainson) (Passeriformes, Trochilidae) [feathers of head, chest, and neck], COSTA RICA: Cerro de la Mueste, 934'N, 834' W, 13 August 2010, coll. I. Literak et al. (CM 152).

27 females (ZISP AVB 10-1210-008, 1-27) from Amazilia lactea (Lesson) (Apodiformes, Trochilidae) [feathers of head and neck], BRAZIL: Minas Gerais, Belo Horizonte, Nova Lima, Área de Proteção Permanente (Permanent area for protection) do Condomínio Migueláo, $20^{\circ} 07^{\prime} \mathrm{S}, 43^{\circ} 58^{\prime} \mathrm{W}, 4$ September 2010, coll. S.V. Mironov et al. (SVM-10-0904-1).

Hosts and distribution. This species was briefly diagnosed from both sexes collected from an unidentified species of hummingbird (Trochilidae) that originated from South America (exact locality unknown) and died in the Zoo of Antwerp (Belgium) during its quarantine. Later on, Fain (1995) provided the full description of this species based on the type specimens and newly obtained specimens from Chrysolampis mosquitus (Linnaeus) (Trochilidae) that also originated in South America (without exact locality) and died in the Zoo quarantine. The trochilids, Panterpe insignis, Eugenes fulgens (Costa Rica), and Amazilia lactea (Brazil) are new hosts for this mite species. It is probable, that this species is associated exclusively with hummingbirds and is widely distributed on representatives of this host family.

Remarks. The longitudinally subdivided dorsal shield of this species is an artifact sometimes induced by the mite mounting. In this species, actually, the dorsal shield is entire. It differs from the closely related $N$. baile Bochkov et al. by the following characters. In females of $N$. trochilinus, setae $d F, d G$, and $l$ " $G$ are subequal, legs III and IV with 5-6 setae each, setae si and se 25-35 long. In $N$. baile, setae $d F$ is about 1.5 times longer than $d G$ and $l$ " $G$, legs III and IV as a rule with 4 setae each, setae $s i$ and se are $6-12$ long. 


\section{Keys to species of the genus Neharpyrhynchus Fain (females)}

(based on Martinu et al. 2008)

1 Anterior margin of propodonotum without ornamentation or just with few striations. Palpal seta $v F$ serrate. Legs II with 4 articulate segments ............ 2 Anterior margin of propodonotum ornamented. Palpal seta $v F$ smooth. Legs II with 2 articulate segments 4 Palpal setae $d F$ 1.4-1.5 times longer than $d G$ and $l " G$. Setae si and $c 2$ short, 6-12 long. Leg IV normally with 4 setae (rarely with 5 setae) 3 Palpal setae $d F, d G$, and $l$ " $G$ subequal in length. Setae si and $c 2$ relatively long, 25-35 long. Leg IV normally with 5 setae (rarely with 6 setae)

N. trochilinus Fain, 1972

Lengths of palpal setae $d F, d G$, and l"G 58-70, 40-49, and 42-53, respectively. Leg III normally with 5 setae (rarely with 4 setae)

N. bochkovi Martinu et al., 2008

Lengths of palpal setae $d F, d G$, and $l " G 45-54,30-44$, and 30-39, respectively. Leg III normally with 4 setae (rarely with 5 setae)

N. baile Bochkov et al., 2007

Legs I with 2 segments; legs IV with 1 segment. Scales on ventral surface of idiosoma absent.

Legs I with 4 segments; legs IV with 2 segments. Scales on ventral surface of idiosoma present N. squamiferus (Fain, 1972)

Setae $3 a$ absent

Setae $3 a$ present

Posterior margin of dorsal shield without distinct median suture. Anterior part of propodosoma ornamented by verrucosities, flat cells or widely rounded scales

- $\quad$ Posterior margin of dorsal shield with distinct median suture reaching $1 / 3$ of shield length. Anterior part of propodosoma ornamented by irregular striae (folds) N. schoenobaenus Martinu et al., 2008 Palpal femur distinctly inflated dorsally. Anterior part of propodonotum ornamented only in posterior half by widely rounded scales Palpal femur moderately inflated dorsally. Anterior part of propodonotum fully ornamented by verrucosities or closed cells . .9 Setae $c 2$ 8-12 long. Posterior margin of dorsal shield almost straight .N. tanagra sp. $\mathrm{n}$.

Setae $c 2$ 50-60 long. Posterior margin of dorsal shield widely concave N. mironovi sp. n. 
9 Anterior part of prodorsum covered by irregularly situated verrucosities, not forming transverse rows. Dorsal shield covered by fine ornamentation. Legs III normally with 4-6 setae.

- $\quad$ Anterior part of prodorsum covered by verrucosities forming 4-5 transverse rows. Dorsal shield without ornamentation. Legs III with 4 setae

N. pilirostris (Berlese \& Trouessart, 1889)

10 Dorsal shield 140-165 long, covered by fine longitudinal striation. Legs III with 5-6 setae.

N. pari Martinu et al., 2008

- $\quad$ Dorsal shield 165-195 long, covered by fine irregular transverse scale-like striation. Legs III with 4-5 setae N. hippolae Bochkov, 2000

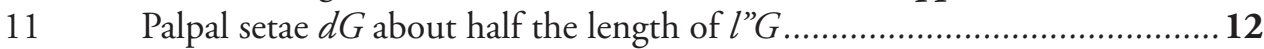

Palpal setae $d G$ and $l$ " $G$ subequal .............................................................. 13

12 Palpal setae $d F$ slightly shorter than $l$ " $G$. Setae se and $c 2$ about 4 times shorter than setae $1 b$. Posterior margin of dorsal shield widely concave......

N. chlorospingus sp. $\mathbf{n}$.

- $\quad$ Palpal setae $d F$ slightly longer than l"G. Setae se and $c 2$ subequal or only slightly shorter than setae 16 . Posterior margin of dorsal shield widely convex ........................................................ novoplumaris Moss et al., 1968

13 Anterior part of propodonotum covered by longitudinal striation only in posterior part. Palpal setae $v F 75-80$ long. Dorsal shield 307-345 wide, covered by fine longitudinal scale-like pattern.

N. plumaris (Fritsch, 1954) Anterior part of propodonotum completely covered by longitudinal striations. Palpal seta $v F 98-108$ long. Dorsal shield 275-280 wide, devoid ornamentation N. spinus Martinu et al., 2008

\section{Acknowledgements}

We thank Dr. S.V. Mironov (ZISP, Russia) who provided us with Neharpyrhynchus samples collected by him in Brazil. We thank Drs. M. Capek, F.A. Hernandes, F. Kounek, M. Literakova, B. Calvo Rodriguez, O. Sychra, and M. Valim for the cooperation in the field. Mites were collected from birds under permits No. 24789-1 (IBAMA, Brazil) and No. 120-2010-SINAC (MINAET, Costa Rica). This research was supported by grants No. 10-04-00160 and No. IAA601690901 from the Russian Foundation for Basic Research and the Grant Agency of the Academy of Sciences of the Czech Republic, respectively.

\section{References}

Berlese A, Trouessart E (1889) Diagnoses d'acariens nouveaux ou peu connus. Bulletin de la Bibliotheque Scientifique de l'Quest 9: 134-140.

Bochkov AV (2000) A first record of mites of the genus Neharpyrhynchus (Acari: Harpirhynchidae) in Russian fauna. Parazitologiya 34: 534-538 [In Russian with English summary]. 
Bochkov AV (2008) New observations on phylogeny of cheyletoid mites (Acari: Prostigmata: Cheyletoidea). Proceedings of the Zoological Institute 312: 54-73.

Bochkov AV, Literak I, Capek M (2007) Neharpyrhynchus baile n. sp. (Prostigmata: Harpirhynchidae) parasitizing Turdus leucomelas Vieillot (Aves: Turdidae) from Brazil. International Journal of Acarology 33: 35-39.

Clements JF, Schulenberg TS, Iliff MJ, Sulivan BL, Wood CL (2010) The Clements checklist of birds of the world: Version 6.5. http://www.birds.cornell.edu/clementschecklist/Clements\%206.5.xls/view [accessed 25 January 2011].

Fain A (1972) Notes sur les families Cheyletidae et Harpyrhynchidae productrices de gales chez les oiseaux ou les mammiferes. Acta Zoologica et Pathologica Antverpiensia 56: 37-60.

Fain A (1995) New observations on the Harpirhynchidae Dubinin, 1957 (Acari: Prostigmata). II. On some new or little-known taxa in the Harpirhynchinae. Bulletin de I'lnstitut Royal des Sciences Naturelles de Belgique, Entomologie 65: 73-100.

Fritsch W (1954) Die Milbengattung Harpyrhynchus Mégnin, 1878 (Subordo Trombidiformes, Fam. Myobiidae Megn. 1877). Zoologischer Anzeiger 152: 177-198.

Grandjean F (1939) Les segments postlarvaires de l'hystérosoma chez les oribates Acariens. Bulletin de la Société Zoologique de France 64: 273-284.

Grandjean F (1944) Observations sur les Acariens de la famille des Stigmaeidae. Archives des Sciences Physiques et Naturelles 26: 103-131.

Grandjean F (1946) Au sujet de l'organe de Claparede, des eupathides multiples et des taenidies mandibulaires chez les Acariens actinochitineux. Archives des Sciences Physiques et Naturelles 28: 63-87.

Kethley JB (1990) Acarina: Prostigmata (Actinedida). In: Dindal DL (Ed) Soil Biology Guide. Wiley \& Sons, New York, 667-754.

Lawrence RE (1959) New mite parasit of African birds (Myobiidae: Cheyletidae). Parasitology 49: 416-438.

Martinu J, Dusbabek F, Literak I (2008) A review of mites of the genus Neharpyrhynchus Fain (Acari: Harpirhynchidae) - ectoparasites of wild birds, including description of four new species. International Journal of Acarology 34: 197-209.

Moss WW (1979) Patterns of host-specificity and coevolution in the Harpyrhynchidae. In: Rodriguez JG (Ed) Recent Advances in Acarology. Academic Press, New York, 2: 379-384. Moss WW, Oliver JH, Nelson B (1968) Karyotypes and developmental stages of Harpyrhynchus novoplumaris sp. n. (Acari: Cheyletoidea: Harpyrhynchidae) a parasite of North American birds. Journal of Parasitology 54: 377-392. 